\title{
A multi-proxy Late-glacial palaeoenvironmental record from Lake Bled, Slovenia
}

\author{
Maja Andrič · Julieta Massaferro - Ueli Eicher • Brigitta Ammann • \\ Markus Christian Leuenberger • Andrej Martinčič • Elena Marinova • \\ Anton Brancelj
}

Published online: 23 May 2009

(C) Springer Science+Business Media B.V. 2009

\begin{abstract}
This study investigates the palaeoecological record $\left(\delta^{18} \mathrm{O}, \delta^{13} \mathrm{C}\right.$, pollen, plant macrofossils, chironomids and cladocera) at Lake Bled (Slovenia) sedimentary core to better understand the response of terrestrial and aquatic ecosystems to Late-glacial climatic fluctuations. The multi-proxy record suggests that in the Oldest Dryas, the landscape around Lake Bled was rather open, presumably because of
\end{abstract}

Electronic supplementary material The online version of this article (doi:10.1007/s10750-009-9806-9) contains supplementary material, which is available to authorised users.

Guest editors: K. Buczkó, J. Korponai, J. Padisák \& S. W. Starratt

Palaeolimnological Proxies as Tools of Environmental

Reconstruction in Fresh Water

M. Andrič $(\bowtie)$

Institute of Archaeology, Scientific Research Centre of the

Slovenian Academy of Sciences and Arts, Novi trg 2,

P.B. 306, 1001 Ljubljana, Slovenia

e-mail: maja.andric@zrc-sazu.si

J. Massaferro

Lab de Biodiversidad Darwin INIBIOMA/CONICET,

San Martin 24, 8400 Bariloche, RN, Argentina

e-mail: julimassaferro@crub.uncoma.edu.ar;

julimassaferro@hotmail.com

U. Eicher · M. C. Leuenberger

Climate and Environmental Physics, Physics Institute,

University of Bern, Sidlerstrasse 5, 3012 Bern,

Switzerland the cold and dry climate, with a trend towards wetter conditions, as suggested by an increase in tree pollen as well as chironomid and cladocera faunas typical for well-oxygenated water. Climatic warming at the beginning of the Late-glacial Interstadial at ca. 14,800 cal yr BP is suggested by an increase in the $\delta^{18} \mathrm{O}$ value, the appearance of Betula and Larix pollen and macrofossils, and a warmth-adapted chironomid fauna. With further warming at ca. 13,800 cal yr BP, broad-leaved tree taxa (Quercus, Tilia, Ulmus), Artemisia, and Picea increase, whereas chironomid data (Cricotopus B) suggest lowering of lake levels. After 12,800 cal yr BP (and throughout the Younger Dryas), the climate was colder and drier, as indicated by lower $\delta^{18} \mathrm{O}$ values, decline of trees,

\section{U. Eicher}

e-mail: info@dialogpersonal.ch

\section{B. Ammann}

Institute of Plant Sciences, University of Bern,

Altenbergrain 21, 3013 Bern, Switzerland

e-mail: brigitta.ammann@ips.unibe.ch

B. Ammann - M. C. Leuenberger

Oeschger Centre for Climate Change Research,

University of Bern, Erlachstrasse 9a, 3012 Bern,

Switzerland

M. C. Leuenberger

e-mail: leuenberger@climate.unibe.ch;

info@oeschger.unibe.ch 
increase of microscopic charcoal, xerophytes and littoral chironomids. A warmer climate, together with the spread of broad-leaved tree taxa and a deeper, more productive lake, mark the onset of the Lateglacial/Holocene transition. These results suggest that terrestrial and aquatic ecosystems at Lake Bled were very dynamic and sensitive to Late-glacial climatic fluctuations.

Keywords Late-glacial Lake Bled . Chironomids · Cladocera · Plant macrofossils · Stable isotopes · Pollen

\section{Introduction}

A new interest has developed in the rapid climatic shifts of the Late glacial of the last glaciation because these shifts were so rapid and of so large amplitude. Even if conditions were very different from the present in several respects, and if direct analogues to future climatic warming may not be correct in detail, we may learn about the behaviour of the systems from the past. This includes both the climatic system and various ecosystems. These data on past changes may also be useful to test models.

The study area is situated at a crossroad between south-central Europe, the southeastern Alps and the Balkan Peninsula. Several biogeographically important issues may therefore be tackled from a detailed study of the Late glacial, e.g. biogeographical questions about the position of refugia of plants and invertebrates and their migration routes. Palaeobotanical and genetic studies suggest that glacial refugia

A. Martinčič

Zaloška cesta 78A, 1000 Ljubljana, Slovenia

e-mail: andrej.martincic@siol.net

E. Marinova

Center for Archaeological Sciences, Katholike

Universiteit Leuven, Celestijnenlaan 200E, 3001 Leuven,

Belgium

e-mail: elena.marinova@bio.kuleuven.be

A. Brancelj

National Institute of Biology, Večna pot 111, P.B. 141,

1101 Ljubljana, Slovenia

e-mail: anton.brancelj@nib.si for coniferous and some deciduous trees were located in the Iberian, Italian and Balkan Peninsulas and in parts of central and eastern Europe (e.g. east of the Alps, Hungarian Plain and River Danube), with Slovenia being located in the vicinity or in central part of the suggested refuge areas (e.g. Willis et al., 2000; Petit et al., 2003; Willis \& van Andel, 2004). For example, it has been suggested that eastern Alps was one of the most important refugia for Fagus sylvatica (Magri et al., 2006), and it is interesting that the study site lies between ranges of two distinctive haplotypes of Pinus sylvestris (Cheddadi et al., 2006).

Previous palynological research in Slovenia suggests that at the beginning of the Late glacial, the vegetation of Slovenia consisted of predominantly herbaceous steppe with few pine trees, but with the climatic warming in the Late glacial, Interstadial woodlands (Pinus, Betula, Picea, Quercus, Corylus, Fagus, Tilia, and Ulmus) were expanding (Culiberg, 1991). However, despite intensive palynological research in the area, studies including radiocarbondated multi-proxy analysis of the sediment are very rare. This article presents the results of such multidisciplinary palaeoecological research on Late-glacial sediment at Lake Bled (Slovenia) to better understand changes of Late-glacial vegetation, climate and hydrology.

Earlier research at Lake Bled focused on studies of the modern carbon budget (e.g. $\delta^{13} \mathrm{C}$ and $\delta^{15} \mathrm{~N}$ analyses) and pollen records from short (ca. $45 \mathrm{~cm}$ ) cores (Molnar et al., 1978; Dolenec et al., 1984; Ogrinc et al., 1997, 1998, 2002; Lojen et al., 1997, 1999). The results of pollen analysis for the last ca. 400 years indicate a forest dominated by Fagus and increasing evidence of human pressure (grazing and agriculture, suggested by Fagus decline and an increase of cereals, buckwheat and maize), followed by diminished human impact indicated by an increase of tree pollen, especially Pinus (Molnar et al., 1978).

In 1982, a 675-cm-long sediment core was taken from the deepest (eastern) part of the basin (Fig. 1), and a multi-proxy study was carried out. Results from analysis of Ostracoda, mosses, sedimentary pigments and pollen (Löffler, 1984; Schultze, 1984, 1988) suggested a Late-glacial age (from the bottom to $550 \mathrm{~cm}$ ), with a pollen assemblage dominated by Artemisia, Pinus and Betula. Subsequently, the vegetation shifted to a mixed oak forest, with Fagus showing up at the beginning of the Holocene. The 


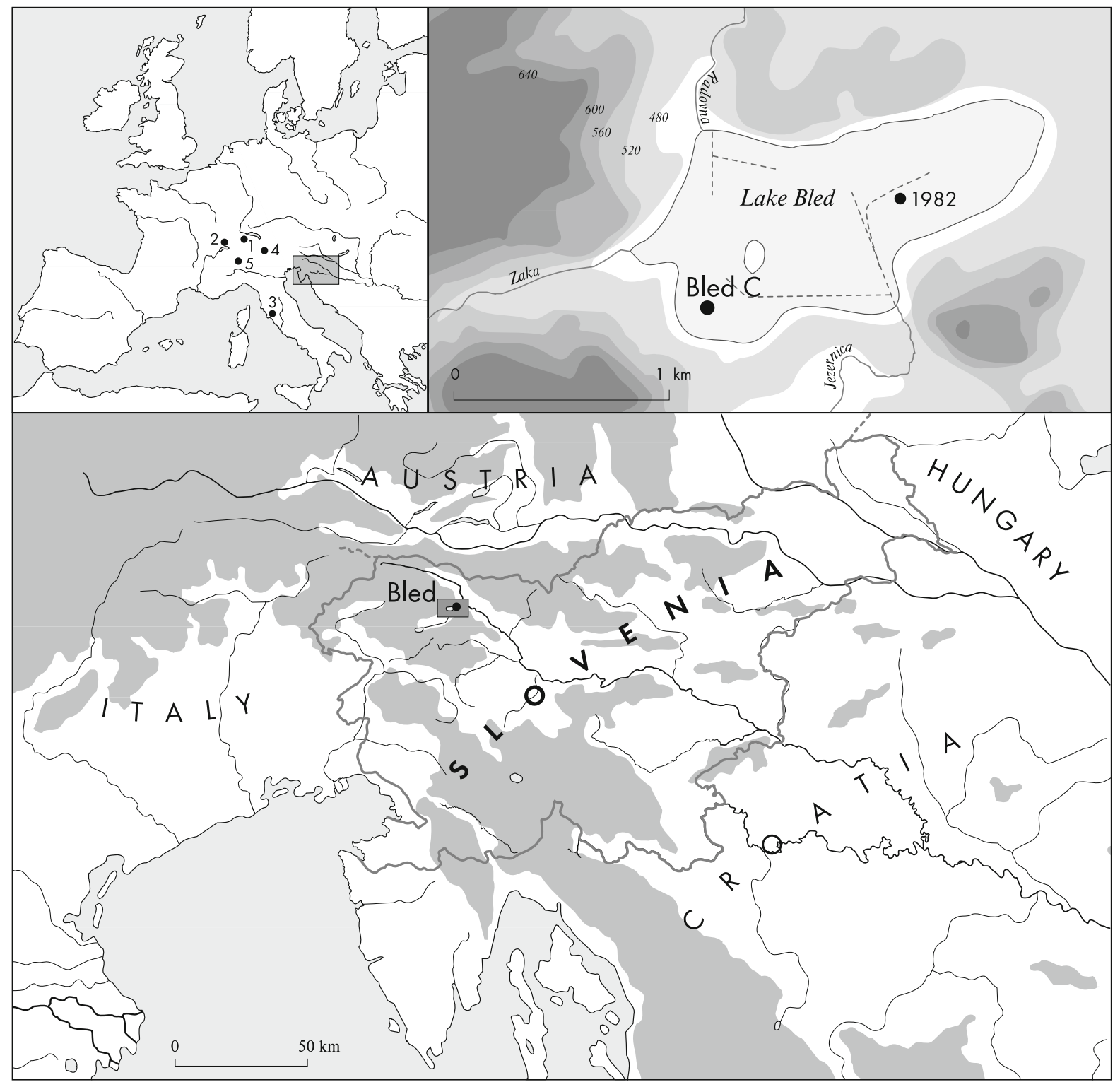

Fig. 1 The geographical position of Lake Bled (Slovenia) and the sediment core. The location of Olszewski tubes is marked by dotted lines. $\bullet 1982$ marks the position of the sediment core collected by Schultze (1984). Study sites, mentioned in Table 3

information about the vegetation during the Holocene at Lake Bled is vague, because sampling resolution in the upper section of the core was rather low $(10-\mathrm{cm}$ interval, no pollen was analysed above $470 \mathrm{~cm}$ ), and the sequence was not radiocarbon dated. Despite the attempt to reconstruct Lake Bled environmental history using a multi-proxy approach, the lack of high sampling resolution and chronological control made it unfeasible. Hence in 2002, to complement the are as follows: 1-Gerzensee, 2-Lake Lautrey, 3- Lake Accesa, 4-Lago di Origlio, 5-Lago Piccolo di Avigliano (study sites on map)

previous study, a new $521-\mathrm{cm}$ sediment core was collected in the southwestern part of the lake and studied to determine the history of the vegetation, hydrology and climate. An age model was constructed using AMS radiocarbon dating and analysis of loss-on-ignition (LOI), stable isotopes $\left(\delta^{18} \mathrm{O}\right.$, $\left.\delta^{13} \mathrm{C}\right)$, geochemistry $\left(\mathrm{CaCO}_{3}\right)$, plant macrofossils, mosses, pollen, chironomids and cladocerans. Results of this research are presented in this article. 
Lake Bled lies in limestone and dolomite bedrock at $475 \mathrm{~m}$ a.s.1. in northwestern Slovenia $\left(46^{\circ} 22^{\prime} \mathrm{N}\right.$, $14^{\circ} 06^{\prime}$ E, Fig. 1). Its maximum depth is $30 \mathrm{~m}$, and covers an area of $1.45 \mathrm{~km}^{2}$ (Grimšičar, 1955; Geological Map of Slovenia, 1993). The lake is surrounded by ground and marginal moraines, with last glacial maximum terminal moraines located to the east of the lake (Grimšičar 1955). The whole valley of the Sava River, where the lake is positioned, is surrounded by high mountains (some of them higher than $2500 \mathrm{~m}$ ) on the west, north and south, and open only to the east. The climate of the area is temperate (average of the coldest month between 0 and $-3^{\circ} \mathrm{C}$, and average of the warmest month between 15 and $20^{\circ} \mathrm{C}$ ), with a submediterranean precipitation regime (1300$2800 \mathrm{~mm}$ annual precipitation with a maximum in autumn) (Ogrin, 1996). In Lesce, ca. $8 \mathrm{~km}$ east of Lake Bled, mean July temperature is $18^{\circ} \mathrm{C}$, mean annual temperature $8.4^{\circ} \mathrm{C}$ and annual precipitation $1541 \mathrm{~mm}$ (Pak, 2001). Forest of predominant beech (Fagus sylvatica) grows to the west and north of the lake, whereas patchy woodlands of hornbeam (Carpinus betulus) and willow (Salix sp.) are located to the east (Čarni et al., 2003). Meadows and agricultural fields are also located in the vicinity of the lake.

Dimictic Lake Bled developed in a depression shaped by a glacier (Radinja et al., 1987). Today, the lake receives water from small natural tributaries (e.g. Zaka River) and artificial inflows (e.g. Radovna River) as well as precipitation. At the beginning of the twentieth century and especially after the Second World War, the lake experienced an increase of nutrient loading from sewage and agriculture, triggering blooms of blue-green algae Oscillatoria rubescens, which threatened the tourist industry. As a consequence, in 1964, clean water from the Radovna River was artificially diverted to the lake $\left(2000 \mathrm{l} \mathrm{s}^{-1}\right)$, and later on in 1980 and 1982, the basin was drained by Olszewski tubes, and domestic sewage was rerouted from the lake (Fig. 1; Radinja et al., 1987). Pumping of hypolimnetic cold water from the bottom of the lake resulted in decrease of nutrients in the water column, and finally in the disappearance of Oscillatoria rubescens (Vrhovšek et al. 1982, 1984, 1985). After several years of anoxic conditions below a depth of 15-18 m during thermal stratification in late summer and late winter, oxygen conditions improved. Nowadays, only short-lasting anoxic events occurred from time to time.

\section{Materials and methods}

Fieldwork

Sediment core Bled C (521-cm-long) was collected from a coring platform in the southwestern part of the lake (Fig. 1) with a Livingstone piston corer (modification after Merkt \& Streif, 1970) with a tube of $4.8 \mathrm{~cm}$ diameter. A single core with 1-m-long core sections was analysed. Water depth at the coring location was $9.6 \mathrm{~m}$. Immediately after extrusion, the core sections were wrapped in thick plastic and stored in the dark at $+4^{\circ} \mathrm{C}$. Subsamples of 1 to $20 \mathrm{~cm}^{3}$ of the sediment (depending on the type of analysis) were analysed with the following techniques: LOI, stable isotope analysis $\left(\delta^{18} \mathrm{O}\right.$ and $\left.\delta^{13} \mathrm{C}\right)$, Chironomidae, Cladocera, pollen and plant macrofossils. AMS radiocarbon measurements were made on selected sections (see below).

Radiocarbon dating, LOI and stable isotope analyses

The age was determined by AMS radiocarbon dating of terrestrial plant macrofossils and bulk organic carbon, extracted from the sediment at 40, 60 and $210 \mathrm{~cm}$ depths (Table 1). Conventional ages were calibrated using CALIB Rev 5.0.1 (CALIB 5.0 Website; Stuiver and Reimer, 1993) on IntCal 04 calibration dataset (Reimer et al., 2004). Median cal yr BP values (as recommended by Telford et al., 2004) were used to construct the age-depth model (linear interpolation; Fig. 2). The percentage of organic material and carbonate in the sediment was determined by LOI at $550^{\circ} \mathrm{C}$ and $950^{\circ} \mathrm{C}$ (Bengtsson and Ennell, 1986). The isotopic composition of oxygen $\left(\delta^{18} \mathrm{O}\right)$ and carbon $\left(\delta^{13} \mathrm{C}\right)$ on bulk carbonate was measured following the conventional method described by Siegenthaler \& Eicher (1986).

Plant macrofossil and moss analyses

For macrofossil analysis, 2.5 -cm sediment slices with volume of approximately $20 \mathrm{~cm}^{3}$ were taken with 10 $\mathrm{cm}$ sampling resolution. After brief soaking (5$10 \mathrm{~min}$ ) in $10 \% \mathrm{KOH}$, the samples were washed through $400-$ and $160-\mu \mathrm{m}$ sieves in two fractions. The material was sorted and identified under stereomicroscope with magnification up to $56 \times$. For determination 
Table 1 Radiocarbon dating in Lake Bled core

\begin{tabular}{|c|c|c|c|c|c|}
\hline Sample no. (material dated, pre-treatment) & $\begin{array}{l}\text { Depth } \\
(\mathrm{cm})\end{array}$ & $\begin{array}{l}\text { Conventional } \\
\text { radiocarbon age }(\mathrm{BP})\end{array}$ & $\begin{array}{l}13 \mathrm{C} / 12 \mathrm{C} \\
\text { ratio }(\%)\end{array}$ & $\begin{array}{l}2 \text { Sigma calibration } \\
\text { (Intcal 04) (BP) }\end{array}$ & $\begin{array}{l}\text { Median } \\
\text { (BP) }\end{array}$ \\
\hline $\begin{array}{l}\text { Beta- } 222472 \\
\text { (Larix leaves, part of cone scale and wings } \\
\quad \text { of coniferous seeds, acid/alkali/acid) }\end{array}$ & 60 & $9340 \pm 40$ & -26.9 & $10679-10426$ & 10555 \\
\hline $\begin{array}{l}\text { Beta-217805 } \\
\text { (Larix twig and needles, acid/alkali/acid) }\end{array}$ & 210 & $11930 \pm 40$ & -28.2 & $13908-13699$ & 13790 \\
\hline $\begin{array}{l}\text { Beta-189953 } \\
\text { (organic sediment, acid washes) }\end{array}$ & 40 & $13860 \pm 100$ & -33.8 & & \\
\hline $\begin{array}{l}\text { Poz-3123 } \\
\text { (organic sediment, acid washes) }\end{array}$ & 40 & $15430 \pm 80$ & / & & \\
\hline
\end{tabular}

The two dates based on terrestrial plant macrofossils (Beta-222472 and Beta-217805) are in good agreement with palynological events in Northern Italy (Vescovi et al., 2007)

The two dates based on organic sediments (Beta-189953 and Poz-3123) are too old and inconsistent with regional events and were not used for age-depth modelling (see text)

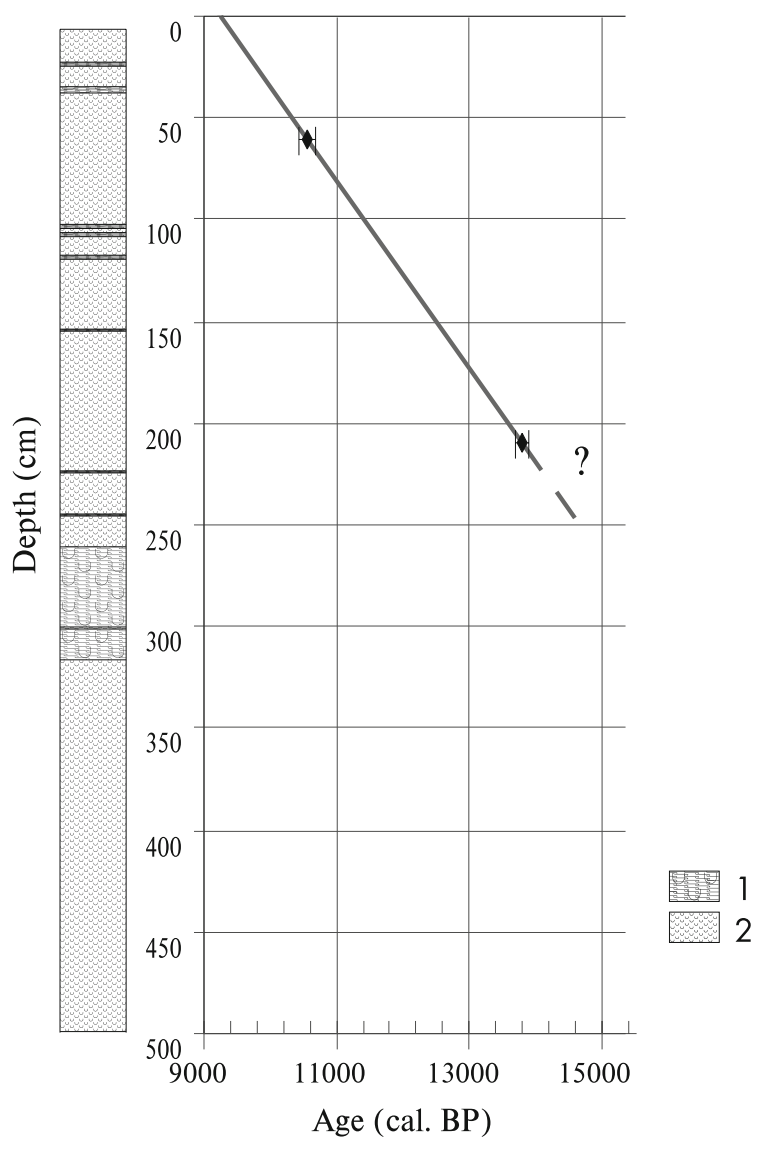

Fig. 2 Age-depth model (linear interpolation). The estimated age of Lake Bled sediment (cal yr BP) is plotted against depth $(\mathrm{cm})$. Details of radiocarbon measurements are presented in Table 2. Lithology: 1-moss layers and 2-calcareous clay (lake marl) of macrofossils, the reference collection from the Herbarium of Sofia University and specialised literature was used (Beijerinck 1947; Katz et al., 1977; Tobolski, 2000). Plant macrofossil concentrations (number of macrofossils in $20 \mathrm{~cm}^{3}$ of the sediment) were integrated in the pollen diagram (Fig. 4). The sample volume was much smaller than that recommended for plant macrofossil analysis (Birks, 2002), and this could affect the results to some extent.

Samples for moss analysis were collected from distinct moss layers at 315, 299, 269, 244, 225, 153, $104,36.5$ and $24.5 \mathrm{~cm}$ and identified under light microscope at $600 \times$ magnification. Keys of Nyholm (1954-1969) and Smith (2004) were used for taxonomic identification.

\section{Pollen analysis}

For pollen analysis, $1 \mathrm{~cm}^{3}$ of the sediment was used following standard laboratory procedures (Bennett \& Willis, 2002). Two tablets with a known number of Lycopodium sp. spores were added prior to laboratory preparation to determine the pollen concentration (Stockmarr, 1971). A minimum of 500 pollen grains of terrestrial plants and spores was counted in each sample, with a sampling resolution of $8 \mathrm{~cm}$. Pollen identification was carried out under a Nikon Eclipse E400 light microscope at $(400 \times$ magnification) using a reference collection of the Institute of Archaeology from Ljubljana and ID keys by Moore et al., 1991 and 
Reille, 1992, 1995. Microscopic charcoal particles and estimation of past fire activity in the area were counted according to the method of Clark (1982). Pollen data were analysed and plotted with the PSIMPOLL 3.00 program (Bennett, 1998; http:// chrono.qub.ac.uk/psimpoll/psimpoll.html). The pollen diagram was divided into five statistically significant pollen zones by the method of optimal splitting by information content (Bennett, 1996, 1998).

\section{Chironomid analysis}

Subfossil chironomid analysis was carried out on 29 samples. Subsamples of $3-4 \mathrm{~cm}^{3}$ wet weight (WW) were deflocculated in $10 \% \mathrm{KOH}$ and heated to $70^{\circ} \mathrm{C}$ for $20 \mathrm{~min}$. The sediment was subsequently passed through 212- and 95- $\mu \mathrm{m}$ mesh sieves. Chironomid larval head capsules were picked out from a Bogorov sorting tray with fine forceps under a stereo microscope at 25-40× magnification. Larval head capsules were mounted in Euparal, ventral side up, under a $6 \mathrm{~mm}$ diameter coverslip. Larvae were identified with reference to Cranston (1997) and Wiederholm (1983). Chrionomid data were processed, analysed and graphed with TILIA v. 1.12, TILIAGRAPH (Grimm 1991) and C2 software (Juggins, 2001, unpublished). The chironomid percentage diagram was created with TILIAGRAPH and C2 graphic tools. In order to detect zones of similar chironomid assemblages within the core, both stratigraphicalconstrained cluster analysis with CONISS and optimal partitioning (Birks \& Gordon, 1985) with ZONE v. 1.2 (Juggins, 1991, unpublished) were used.

\section{Cladocera analysis}

Cladoceran analysis was carried out on 1-g wet weight sediment on the same 29 depths as for chironomid analysis. Samples were washed under a $50-\mu \mathrm{m}$ sieve to remove fine mineral and organic particles. The material left on the mesh was analysed for Cladocera remains (for details see Korhola \& Rautio, 2001). Most of the samples were screened under stereomicroscope at magnification of 40 or $100 \times$. Due to the very low concentration of Cladocera remains, the whole sample was analysed, and only qualitative results can be presented.

\section{Results}

Radiocarbon dates, LOI and stable isotopes

The results of radiocarbon measurements are presented in Table 1. Radiocarbon dates of organic sediment at $40 \mathrm{~cm}$ (Beta-189953 and Poz-3123; Table 1) were not used in the age-depth model due to the errors presumably caused by the reservoir effect (i.e. hard-water effect). Linear interpolation between median values of radiocarbon dates at $210 \mathrm{~cm}$ and $60 \mathrm{~cm}$ was used for age-depth modelling (Fig. 2), suggesting that most of the Holocene sediment is missing. Conversely, Late-glacial and early-Holocene sediments deposited between 13,790 ca. and 10,555 cal yr BP show an average sedimentation rate of $0.046 \mathrm{~cm} \mathrm{yr}^{-1}$. The Holocene sediment is often absent on subaquatic (littoral) terraces and is usually explained by either non-sedimentation or erosion due to wave action (Digerfeldt, 1986), lower lake levels (Scholz, 2001) and movement of sediment from littoral to profundal zone following breakdown of thermocline (Davis, 1976, after Dearing \& Foster, 1986) during the early Holocene and/or after the basin was drained by Olszewski tubes.

The amount of organic material, carbonate and the remaining (after burning at $950^{\circ} \mathrm{C}$ ) inorganic residue was obtained by LOI and was calculated as a percentage of the sediment dry weight (Fig. 3). LOI shows that below $310 \mathrm{~cm}$, there is a high percentage of inorganic material $(65-75 \%)$ remaining. The percentage of organic material stays low throughout the core, whereas carbonate increases to $40 \%$ (and the remaining inorganic material decreases to 55\%) above $270 \mathrm{~cm}$.

The samples below $400 \mathrm{~cm}$ show positive $\delta^{13} \mathrm{C}$ values $\left(+1 \%\right.$ ), whereas $\delta^{18} \mathrm{O}$ values are ca. $-5 \%$ and $\mathrm{CaCO}_{3} 40-45 \%$ (Fig. 3). At about $300 \mathrm{~cm}$, carbonates increase to ca. $80 \%, \delta^{13} \mathrm{C}$ values are negative and a decrease of $\delta^{18} \mathrm{O}$ to ca. $-10.50 \%$ is observed between 300 and $262 \mathrm{~cm}$. The $\delta^{18} \mathrm{O}$ values decrease sharply between depths of $168-$ and $152-\mathrm{cm}$, and the values remain at these low values until $102 \mathrm{~cm}$ but with a slightly increasing trend towards shallower depth. The upper part of the profile from $102 \mathrm{~cm}$ up to $50 \mathrm{~cm}$ (some sediment is missing due to coring problems) exhibits a step-like increase by $0.8 \%$. Towards the core surface, the values remain relatively high at $-8.1 \%$. 
Bled C. Loss-on-ignition.

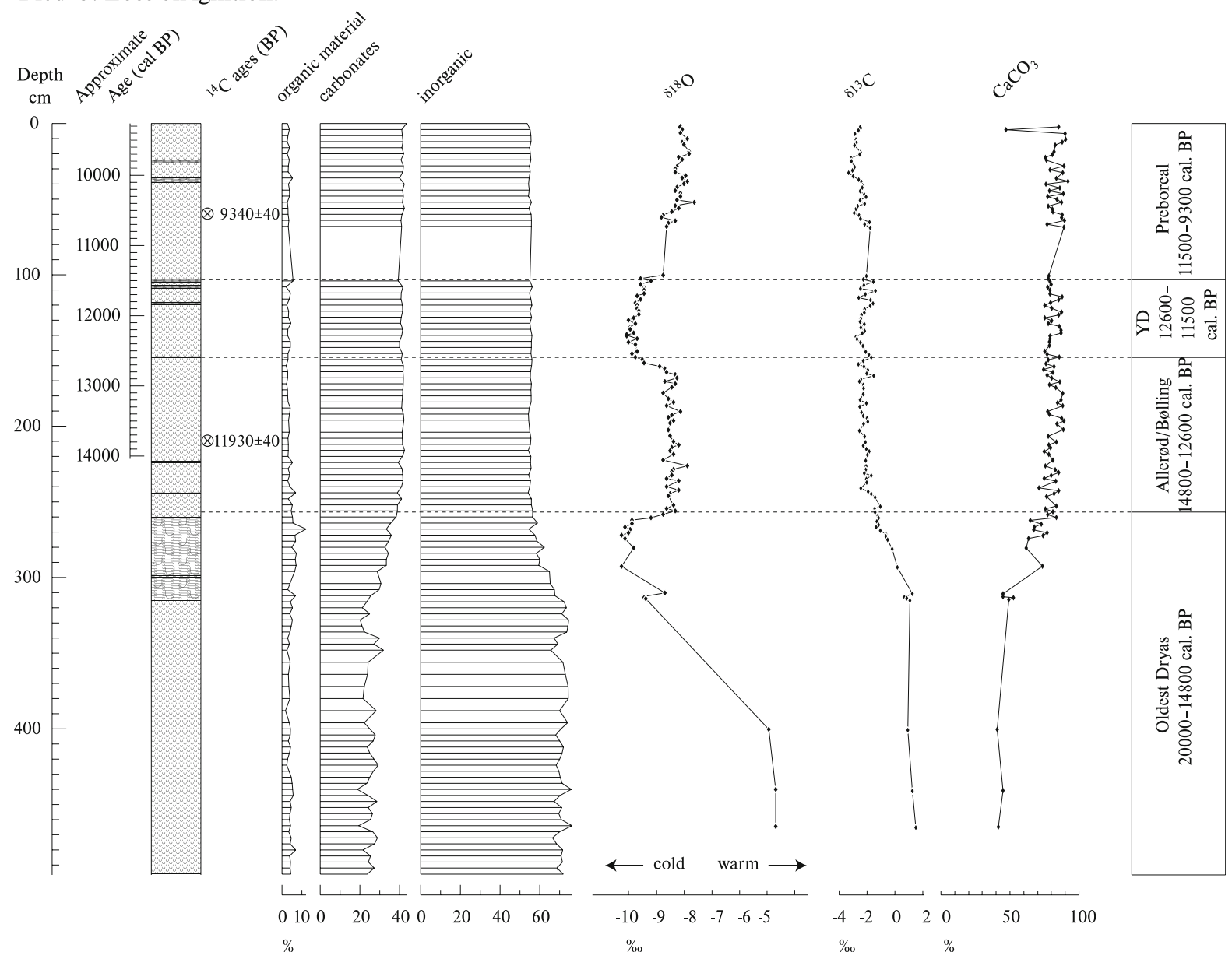

Fig. 3 Chronology and physical and chemical characteristics (loss-on-ignition: organic material, carbonates, inorganic residue; stable isotopes: $\delta^{18} \mathrm{O}, \delta^{13} \mathrm{C} ; \mathrm{CaCO}_{3}$ ) of a sediment core Bled $\mathrm{C}$

Plant macrofossils and moss

Moss layers were found between 315 and $223 \mathrm{~cm}$, 155 and $107 \mathrm{~cm}$, and 29 and $24 \mathrm{~cm}$, with a thick moss layer between 315 and $260 \mathrm{~cm}$, (indicated as dark horizontal lines in sedimentary column of Figs. 3, 4a, $\mathrm{b}, 5,6)$. Moss species recovered belong to the genera Scorpidium ( $S$. scorpioides), Pseudocalliergon ( $P$. trifarium) and Calliergon (Calliergon cf. C. cordifolium-giganteum). Plant macrofossils appear only in the upper part of the sequence (from ca. $320 \mathrm{~cm}$ upward), and the dominant assemblages are a combination of needles of Larix and Betula catkins. Picea (and Populus in B-5) macrofossils appear in the last two pollen zones (Fig. 4a).
Pollen

Due to the poor preservation and low concentration of pollen in pollen zones B-1 and B-2 (496-390, 390$315 \mathrm{~cm}$ ) (ca. 500 pollen grains per $1 \mathrm{~cm}^{3}$ of wet sediment, with more than $20 \%$ of degraded pollen grains, Fig. 4b), the pollen sum in most of the samples was below the statistically required minimum (300 grains per count). The main taxa present are Pinus and herbs. In pollen zone B-3 $(315-200 \mathrm{~cm})$, pollen concentration increases to ca. 2000-30,000 pollen grains $\mathrm{cm}^{-3}$, with high percentage of Pinus (ca. 7595\%) and much lower percentage of herbs than in the previous two zones. At the beginning of pollen zone B-4 $(200-115 \mathrm{~cm})$, the percentage of Pinus starts to 


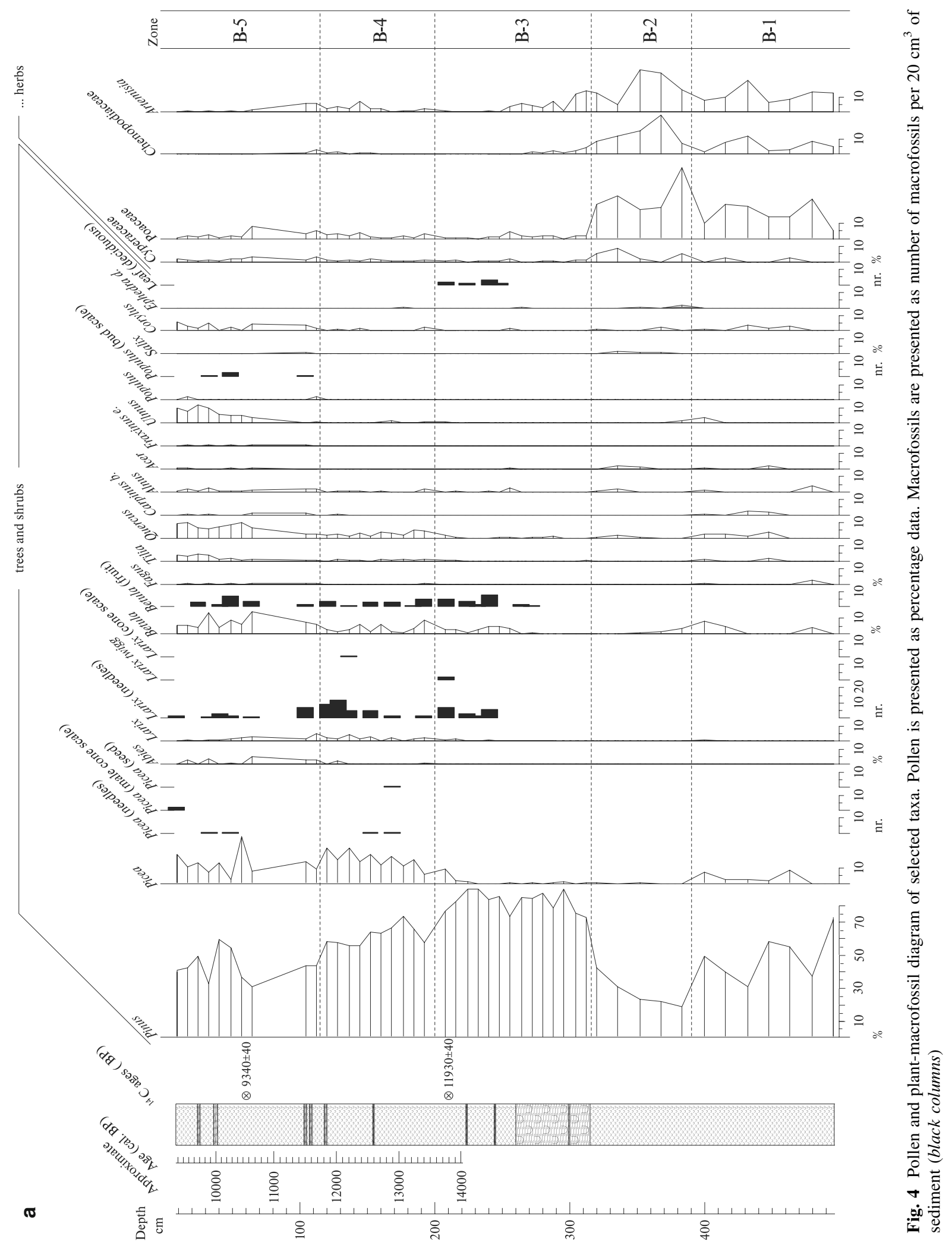




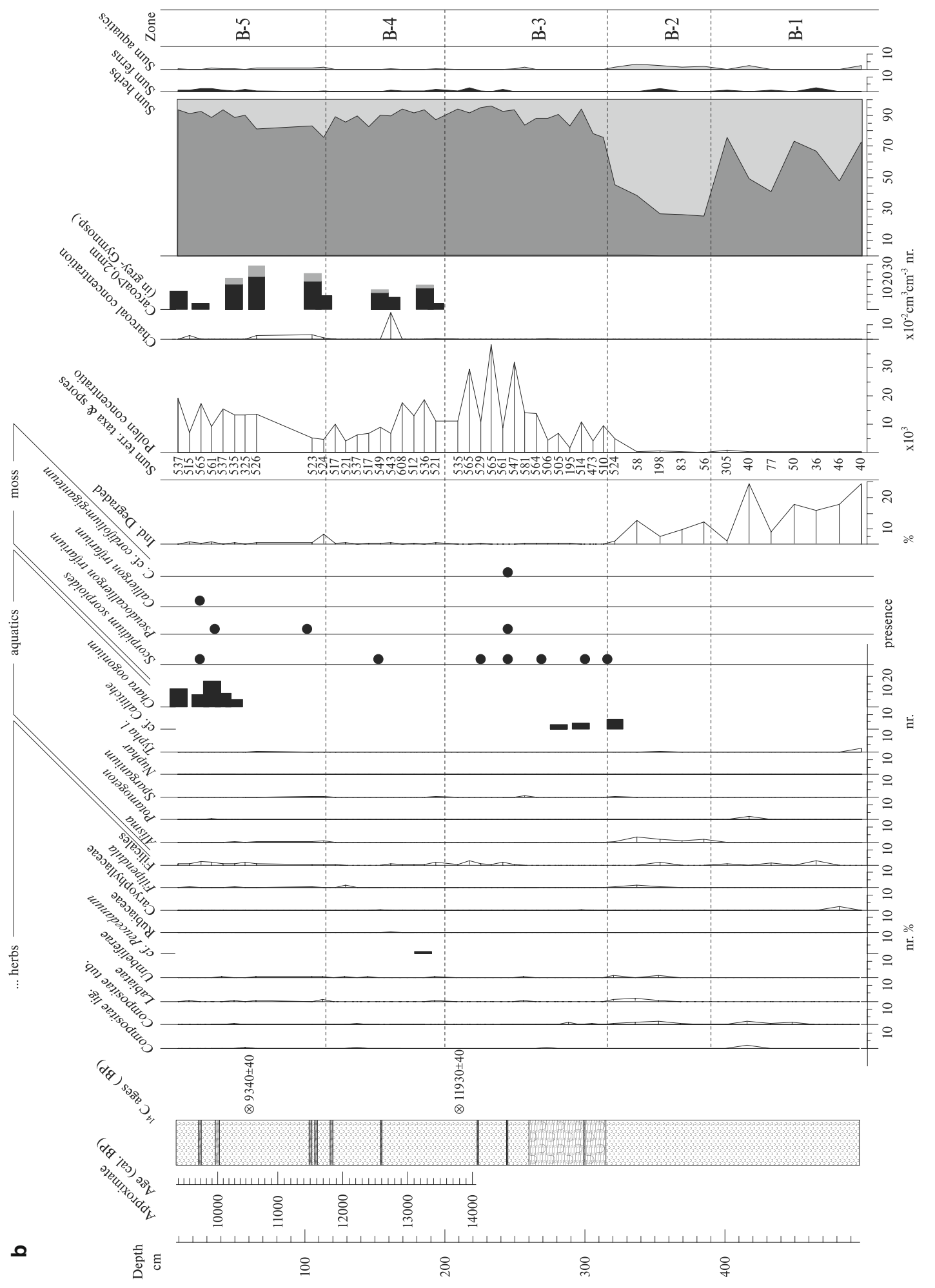

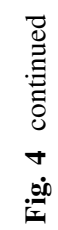


decline, whereas other tree taxa (Picea, Larix, Tilia, Ulmus, Quercus, Corylus) increase with short tree taxa declining in the upper half of the zone (160$115 \mathrm{~cm})$. Finally, at the beginning of zone B-5 (115$0 \mathrm{~cm})$, tree taxa start to increase again. In pollen zones B-4 (192 and $160 \mathrm{~cm})$ and especially B-5 (104, 64, and $16 \mathrm{~cm}$ ), charcoal peaks occur more frequently than in the lower part of the core.

\section{Chironomids}

A total of 28 chironomid taxa were identified in the Lake Bled sediment sequence (for taxonomic notes, see Electronic supplementary material), and the distribution of selected taxa is shown in Fig. 5. Optimal partitioning and CONISS analysis allowed us to recognise six zones along the core: Zone Ch-1 (496-312 cm) was devoid of chironomids below $336 \mathrm{~cm}$. At the top of this zone, head-capsule concentrations were very low, and in most samples, not more than 20 head capsules were counted. Cold stenohermic taxa such as Paracladius and Heteotrissocladius were present. At the top of the zone, warmadapted Chironomus antracinus and Tanytarsus B appear. Zone Ch-2 (312-264 cm) is characterised by the increase of Micropsectra radialis and the appearance of Paratanytarsus penicillatus and several species of the cold stenothermic Heterotrisocladius. At the beginning of the zone Ch-3 $(264-200 \mathrm{~cm})$, a decline in $M$. radialis coincides with an increase in $P$. penicillatus. Appearing for the first time are Chironomus plumosus and Arctopelopia. Zone Ch-4 $(200-168 \mathrm{~cm})$ is characterised by the decrease of $M$. radialis and Ch. antracinus, and the increase of Cricotopus B, and specially Arctopelopia and Parakiefferiella. In zone Ch-5 $(168-120 \mathrm{~cm})$, Cricotopus $\mathrm{B}$ reaches its maximum value. In Zone Ch-6 (120$90 \mathrm{~cm}$ ), there is a decrease in the number of head capsules. The zone is characterised by the increase of $M$. radialis and the decease of $P$. penicillatus, T. chineyensis, Arctopelopia and Cricotopus B. In zone Ch-7 $(90-0 \mathrm{~cm})$, there is a marked drop in $M$. radialis mirrored by the increase of $P$. penicillatus.

\section{Cladocera}

Very few remains of Cladocera (always $>10$ remains $\mathrm{g}^{-1}$ ) were found in the sediment, and only head shields and valves were used to identify them to the species level. In total, only four taxa of Cladocera (all species are benthic) were detected along the core: Acroperus harpae, Alona affinis, Alonella nana and Chydorus sphaericus (Table 2). No Cladocera remains were present below the depth of $272 \mathrm{~cm}$, and neither Ostracoda nor Mollusca were found below $320 \mathrm{~cm}$. The most common species recovered in most of the samples up to the depth of $272 \mathrm{~cm}$ was Alona affinis, found in 10 samples (out of 13). The section between $48 \mathrm{~cm}$ and the top of the core is characterised by very poor Cladocera assemblage, with no remains or very low concentrations of $A$. affinis and A. harpae.

\section{Discussion}

Oldest Dryas, undated, presumably $>$ ca. 14,800 cal yr BP $(496-260 \mathrm{~cm})$

The isotope values from the deepest part of the core below ca. $300 \mathrm{~cm}$ are influenced by micritic, allochtonous carbonates, transported into the lake from the surrounding watershed; therefore, they cannot be used to determine temperature (Lister 1988; Finsinger et al., 2008). Below $336 \mathrm{~cm}$, no biological remains were found, except for pollen in very low concentrations. This absence of fauna could be related to the low percentage of organic matter and extremely cold waters, making insufficient food for animals to survive. Soon after, at $325 \mathrm{~cm}$, macrofossil remains of Callitriche indicate very shallow water at the coring point. A rather high percentage of herbaceous pollen (e.g. Poaceae) and xerophytes ( 10-50\%, e.g. Chenopodiaceae and Artemisia, Pinus stays around $50 \%$, Picea goes up to almost 10\%, Fig. 4a and 6) suggests that the landscape was rather open, presumably due to cold and dry climate. Sporadic pollen (but no macrofossils) of broad-leaved tree taxa such as Quercus, Ulmus, Tilia, Carpinus, Acer and Fagus probably does not reflect local vegetation and can be linked to two possible sources: either long-distance transport or reworking from older sediment. If we compare Lake Bled palaeoecological record with other study sites in northern Italy and southern Switzerland (e.g. Lago di Origlio, Lago Piccolo di Avigliano and Lago della Costa with local presence of Larix and Betula in LGM, Kaltenrieder et al., in press a), a similar silty clay is visible above glacial 


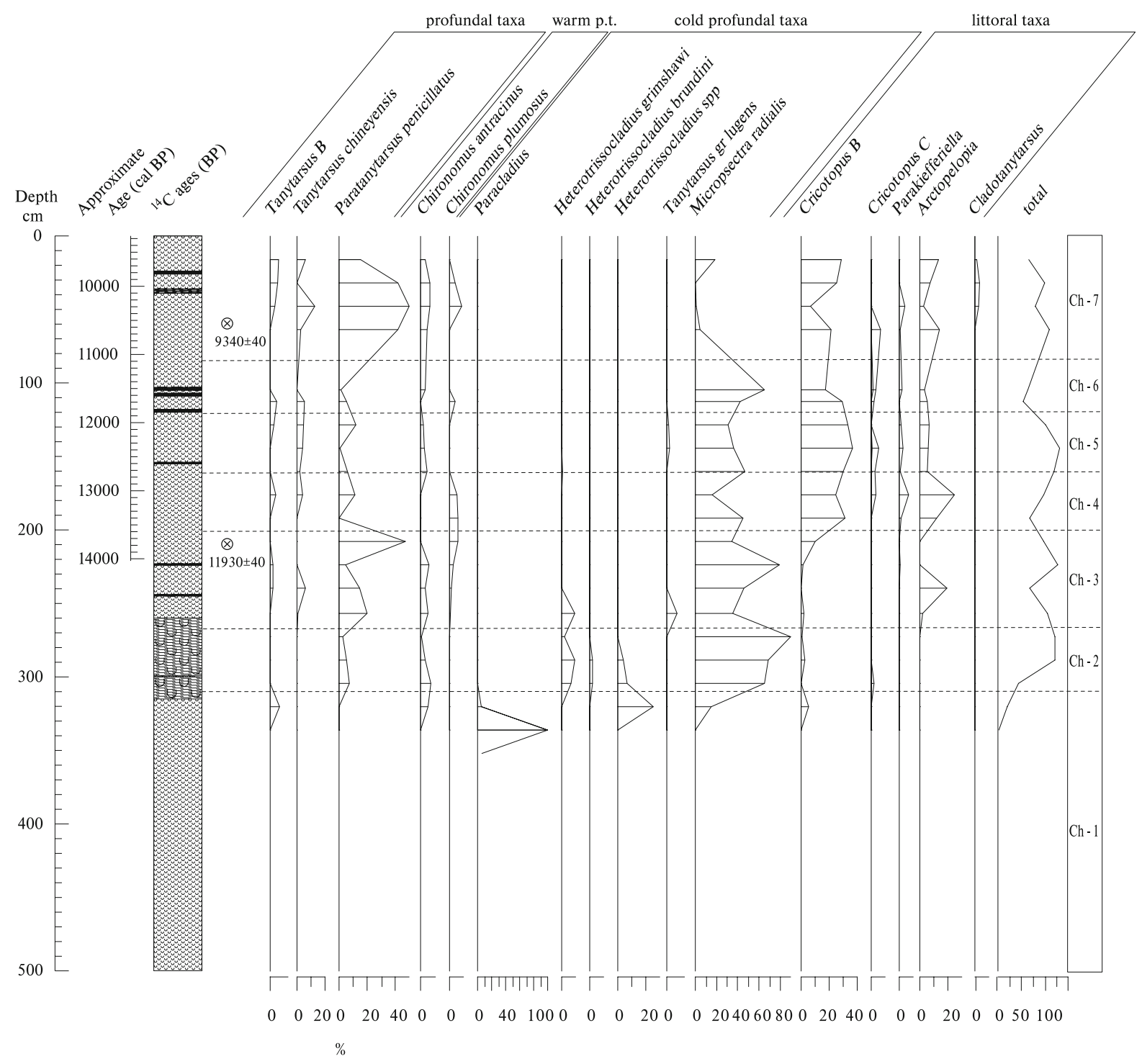

Fig. 5 Chironomid stratigraphy. Data are presented as percentage of relative abundance plotted against depth $(\mathrm{cm})$. Only selected taxa are shown

till (at ca. 18,000 cal yr BP), after glacial retreat. Pollen, stomata and plant-macrofossil data from those study sites suggested that before $16,000 \mathrm{cal} \mathrm{yr} \mathrm{BP,}$ the lowlands of northern Italy and southern Switzerland were not yet covered by dense forest vegetation (Vescovi et al., 2007, Table 3). A similar vegetation, namely an herb-dominated steppe tundra, probably with some shrubs of Salix and Betula, was growing also around Lake Bled. The presence of Pinus and Picea trees cannot be completely ruled out, although plant macrofossils, proving that they were growing in the vicinity of the lake, were not found.

Results from the Lake Bled core during the Oldest Dryas are in accordance with palaeoclimatic research based on a simple glacier-flow model and statistical glacier-climate models of the Gschnitz glacier (IvyOchs et al., 2006b) suggesting that during the Gschnitz cold period (from 19,000 to $18,000 \mathrm{cal}$ yr $\mathrm{BP}$, coinciding with Heinrich 1 ice rafting event), the precipitation was about one-third of modern-day 


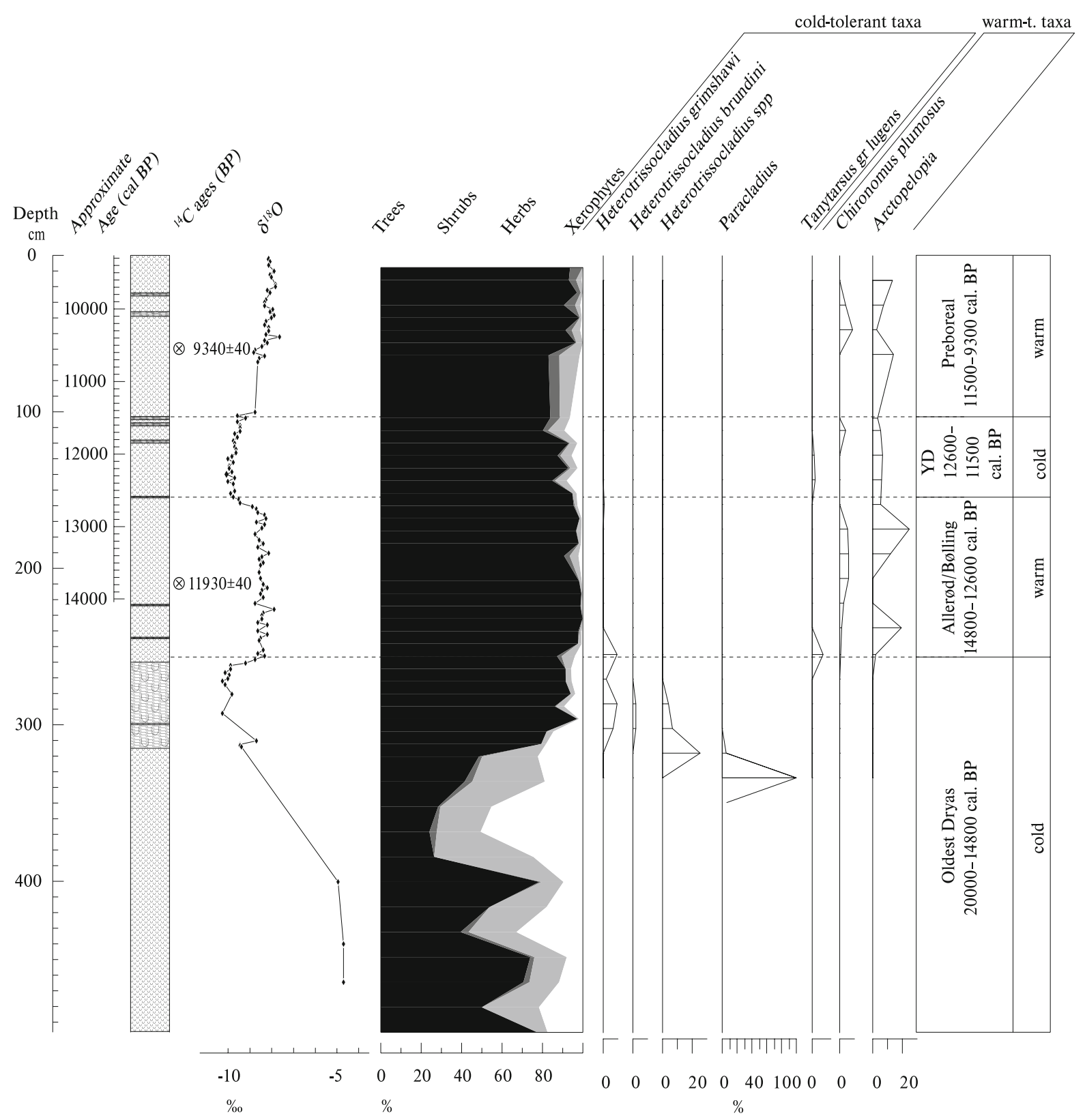

Fig. 6 Comparison of selected multi-proxy data (stable isotopes- $\delta^{18} \mathrm{O}$, pollen and chironomid—in percentages) plotted against depth and estimated age

values, and summer temperatures were around $10^{\circ} \mathrm{C}$ lower than today (Ivy-Ochs et al., 2006a; Kerschner \& Ivy-Ochs, 2008). Also, pollen- and chironomidinferred reconstructions of Oldest Dryas episode for Lake Lautrey (E France) suggest a $3.0-5.5^{\circ} \mathrm{C}$ lower temperature of the warmest month than today and a drier climate (Peyron et al., 2005, Table 3). Similarly, drier Late-glacial climate was suggested for easterncentral Europe by quantitative, pollen-based methods (Feurdean et al., 2008).

Later on (at $315 \mathrm{~cm}$ depth), the palaeoecological record of Lake Bled changes significantly with negative $\delta^{13} \mathrm{C}$ values, and $\mathrm{CaCO}_{3}$ (most probably of biogenic origin, as suggested by the appearance of 
Table 2 Cladocera remains (presence/absence analysis) and some other groups of organisms (mollusca, ostracoda) from Lake Bled

\begin{tabular}{|c|c|c|c|c|c|c|c|c|}
\hline $\begin{array}{l}\text { No. of } \\
\text { sample }\end{array}$ & $\begin{array}{l}\text { Depth } \\
(\mathrm{cm})\end{array}$ & $\begin{array}{l}\text { Acroperus } \\
\text { harpae }\end{array}$ & $\begin{array}{l}\text { Alona } \\
\text { affinis }\end{array}$ & $\begin{array}{l}\text { Alonella } \\
\text { nana }\end{array}$ & $\begin{array}{l}\text { Chydorus } \\
\text { spahericua }\end{array}$ & Ostracoda & Mollusca & Mosses \\
\hline 1 & 16 & $X$ & $X$ & & & $X$ & & \\
\hline 2 & 32 & & & & & $X$ & & \\
\hline 3 & 48 & & & & & $X$ & $\mathrm{X}$ & \\
\hline 4 & 64 & $\mathrm{X}$ & $\mathrm{X}$ & $\mathrm{X}$ & $\mathrm{X}$ & $\mathrm{X}$ & $\mathrm{X}$ & \\
\hline 5 & 112 & $X$ & $X$ & & & $X$ & $X$ & \\
\hline 6 & 128 & $\mathrm{X}$ & $\mathrm{X}$ & & & $\mathrm{X}$ & & \\
\hline 7 & 144 & & $\mathrm{X}$ & & & $\mathrm{X}$ & & \\
\hline 8 & 160 & $\mathrm{X}$ & $\mathrm{X}$ & $\mathrm{X}$ & & $\mathrm{X}$ & & \\
\hline 9 & 176 & $\mathrm{X}$ & $\mathrm{X}$ & & & $\mathrm{X}$ & & \\
\hline 10 & 192 & & $\mathrm{X}$ & & & $\mathrm{X}$ & & \\
\hline 11 & 208 & & $\mathrm{X}$ & & & $X$ & & \\
\hline 12 & 224 & & & & & $X$ & & $X$ \\
\hline 13 & 240 & $\mathrm{X}$ & $X$ & & & $X$ & & \\
\hline 14 & 256 & & $\mathrm{X}$ & & & $X$ & & \\
\hline 15 & 272 & & $\mathrm{X}$ & & & $\mathrm{X}$ & & $\mathrm{X}$ \\
\hline 16 & 288 & & & & & & & $\mathrm{X}$ \\
\hline 17 & 304 & & & & & $X$ & & $X$ \\
\hline 18 & 320 & & & & & $X$ & & \\
\hline 19 & 336 & & & & & & & \\
\hline 20 & 352 & & & & & & & \\
\hline 21 & 368 & & & & & & & \\
\hline 22 & 384 & & & & & & & \\
\hline 23 & 400 & & & & & & & \\
\hline 24 & 416 & & & & & & & \\
\hline 25 & 432 & & & & & & & \\
\hline 26 & 448 & & & & & & & \\
\hline 27 & 464 & & & & & & & \\
\hline 28 & 480 & & & & & & & \\
\hline 29 & 496 & & & & & & & \\
\hline
\end{tabular}

ostracoda and Callitriche macrofossils) increases to $80 \%$. Low $\delta^{18} \mathrm{O}$ values $(-10.5 \%)$ indicate low temperatures. However, climate conditions were rather favourable (increased availability of moisture) and supported the growth of macrophytes, as suggested by the presence of a 55-cm thick Scorpidium scorpidioides moss layer at a depth of $315-260 \mathrm{~cm}$, which was most probably growing 'in situ'. In Slovenia today, this moss grows in marshy areas on wet soil or in shallow ( $<1 \mathrm{~m}$ depth) permanent wet pools (Martinčič, 1996). However, from the literature, it is also known that Scorpidium spp. can grow in shallow lakes up to 20-m depth (Light \& Smith
1976). All moss taxa discovered in Lake Bled tolerate various climatic conditions, and can be found from subarctic to southern Europe today (with the exception of the Mediterranean), at 250-1200 m a.s.l. The chironomid assemblage consists of a typical coldprofundal fauna represented by Micropsectra radialis and several species of genera Heterotrissocladius and Paracladius, typical for well-oxygenated waters. All Cladocera remains are present in a much lower concentration than in present-day samples from other Slovenian lakes (Brancelj et al., 2002). All are benthic and very eurytopic (ubiquitous), tolerant of high oscillations of physical and chemical 


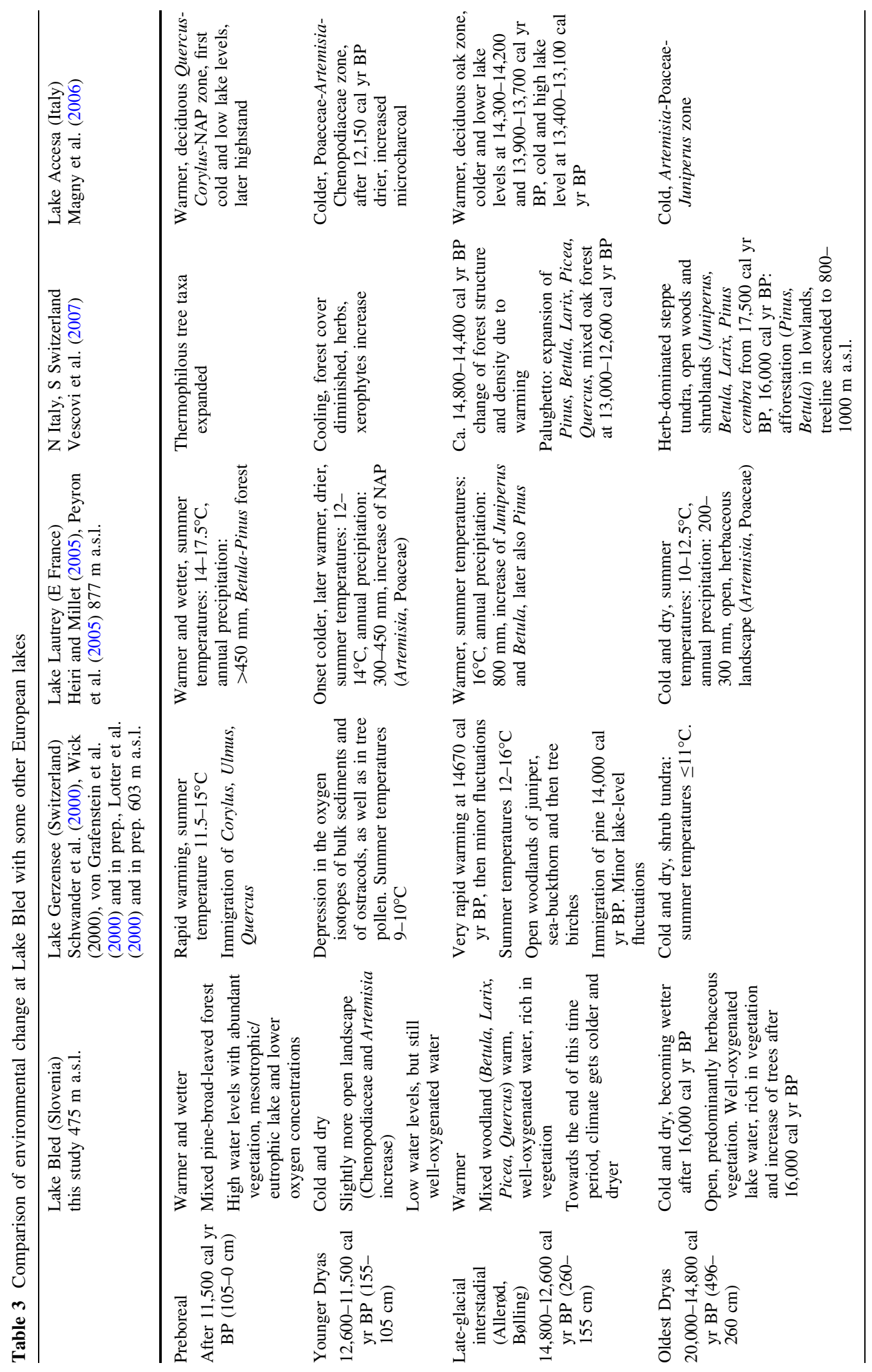


parameters. Alona affinis is common in different types of stagnant water, but it prefers an environment rich in vegetation, either algae or macrophytes (e.g. dense moss stands growing in the lake). This suggests that although climatic conditions were still cold, lake water was well oxygenated and warm enough to support the growth of macrophytes.

Better pollen preservation, as well as, an increase of Pinus and decline of herbaceous taxa indicate moist conditions. Arboreal pollen (mostly Pinus) starts to increase above $315 \mathrm{~cm}$, but the first tree macrofossils (Betula catkins, demonstrating that Betula was present close to the lake margin) occur only at $270 \mathrm{~cm}$. Although the percentage values for Pinus are rather high $(75-95 \%,>14,000$ cal yr BP), surprisingly no macrofossils were discovered in the core. It is possible that either only very few pine trees were growing in the vicinity of the lake, or pine pollen came from long-distance transport. Local absence of plants cannot be proved by the absence of macrofossils for taphonomic reasons, as they have much more limited dispersal than pollen, and macrofossils of terrestrial taxa tend to be under-represented in fossil assemblages (Birks, 2003; Jackson \& Booth, 2007). Pinus pollen accumulation rates (PAR) in dated section of the core (with exception of 13,300$12,800 \mathrm{cal}$ yr BP interval) are, namely, below the threshold value for the presence of local pine $(=500$ pollen grains $\mathrm{cm}^{-2} \mathrm{yr}^{-1}$ ) according to the modern PAR studies in the Alps and in Scandinavia (van der Knaap et al., 2001; Seppä \& Hicks, 2006). Taphonomic reasons for the absence of Pinus macrofossils are not excluded, especially in the depth between 315 and $260 \mathrm{~cm}$ characterised by a moss layer. Such moss vegetation, if growing in very shallow water, can also play a role of 'filter' for the macrofossils. No pine wood or charcoal was found in the vicinity of the lake, but Pinus wood, discovered in Late-glacial sediment of the Soča River valley ca. $50 \mathrm{~km}$ to the west, was radiocarbon dated to $12,450 \pm 70 \mathrm{BP}$ (14,205-14,959 cal yr BP) (Culiberg, 1991). A similar change in vegetation composition at $16,000 \mathrm{cal} \mathrm{yr}$ BP is noticeable in northern Italy, with pollen, stomata, and plant-macrofossil data indicating afforestation by Pinus and Betula (and termophilous taxa at Lago della Costa, Kaltenrieder et al., in press b) between 16,000 and $15,800 \mathrm{cal} \mathrm{yr} \mathrm{BP}$, and the treeline shifted to $800-1000 \mathrm{~m}$ a.s.l. due to an increase in temperature (Vescovi et al., 2007).
Late-glacial interstadial, undated before 13,790 cal yr BP, presumably ca.

$14,800-12,600$ cal yr BP (260-155 cm)

Climatic warming at the beginning of the Late-glacial interstadial is suggested by $\delta^{18} \mathrm{O}$ increase by $1.5-2 \%$ to ca. $-8.5 \%$ (Fig. 3 ). Warmer condition is also suggested by the pollen and plant-macrofossil record (Figs. 4a, b). Pollens of tree taxa (e.g. Betula) and Larix increase, whereas plant-macrofossil records suggest that Larix and Betula (after 13,000 cal yr BP also Picea) were growing on the lakeshore. The coldadapted chironomid Micropsectra radialis and Heteroterissocladius spp. disappear and warm-adapted fauna, such as the representatives from the Pentaneurini tribe, appear. A mixed warm-adapted chironomid fauna including Arctopelopia, Dicrotendipes, Chironomus pulmosus and Tanytarus chineyensis appears, indicating that although the lake became warmer and probably more productive, it was still well oxygenated. Also, the presence of littoral-dweller cladoceran Acroperus harpae, together with Alona affinis, which is a common inhabitant in modern littoral vegetation, suggests warm water. Similar environmental change was also detected in northern Italy and southern Switzerland between 14,800 and 14,400 cal yr BP, when abrupt changes in forest composition and density were associated with climatic warming (von Grafenstein et al., 2000; Lowe et al., 2001; Heiri \& Millet, 2005; Vescovi et al., 2007), which is also in accordance with northern-hemispheric reconstructions (Björck et al., 1998; Lowe et al., 2008). Besides, pollen- and chironomid-inferred temperatures for the Lake Lautrey suggest strong climatic warming and increase of precipitation by that time (Peyron et al., 2005). Also pollen-based climate estimations for northwestern Romania suggest summer temperatures close to modern values (Feurdean et al., 2008). Further in south east, the increasing moisture availability is recorded by the palynological and plant macrofossil assemblages of the Rila, Pirin Mountains (Bozilova et al., 1996; Stefanova \& Ammann, 2003) and Thracian Plain (Magyari et al., 2008). At Lake Bled, the local presence of Picea in the late Alleröd, as indicated by macroremains, demonstrates the more easterly position of refugia in the southeastern Alps and southwestern Carpathians, as indicated by van der Knaap et al. (2005), Latałowa \& van der Knaap (2006), Ravazzi et al. (2006), Vescovi et al. (2007) and Feurdean et al. (2007). 
A change in vegetation composition also occurs at ca. 13,800 cal yr BP. The decrease of Pinus and the increase of Quercus, Tilia, Ulmus, as well as Artemisia (drier) and Picea could be linked to warmer conditions, although stable isotope record at Lake Bled does not show significant increase of $\delta^{18} \mathrm{O}$. A sharp increase of chironomid larvae of Cricotopus $B$ at the same time suggests that the lake levels decreased. Again, similar vegetation change and lowering of lake levels occurred over a wider area on the southern side of the Alps (Vannière et al., 2004; Magny et al., 2006; Vescovi et al., 2007).

After $12,800 \mathrm{cal}$ yr BP, $\delta^{18} \mathrm{O}$ started to decrease, suggesting climatic cooling. Climate was possibly also getting drier, as suggested by the increase of microcharcoal concentrations, the decline of pollen of tree taxa, the increase of xerophytes and the presence of littoral chironomids Parakiefferiella, Arctopelopia and Cricotopus.

Younger Dryas, 12,600-11,500 cal yr

BP $(155-105 \mathrm{~cm})$

Oxygen-isotope records indicate that both the onset and termination of Younger Dryas as recorded in the presented Lake Bled record are remarkably sharp (Fig. 3). Climatic conditions during the Younger Dryas were cold $\left(\delta^{18} \mathrm{O}-9.7 \%\right.$ ) and dry, as suggested by the increase of Chenopodiaceae and Artemisia, and the recurrent presence of moss layers. Chironomid taxa are mostly littoral, suggesting that throughout the YD the lake was probably shallow. The presence of Alonella nana, which is common in the environment rich in organic debris and well oxygenated water, is also an indication of cold and dry conditions. Among the trees, Larix (cold and drought adapted species, also present at other sites in central and eastern Europe, e.g. Willis et al., 2000; Feurdean et al., 2007) is more abundant than Quercus, as in northern Italian pollen records (Vescovi et al., 2007). The palaeoecological records at Lake Lautrey (Peyron et al., 2005) and Gerzensee (von Grafenstein et al., 2000; Lotter et al., in prep.) also suggest colder and drier climate, although lake level at Gerzensee was $1.7 \mathrm{~m}$ higher than today $(0.4 \mathrm{~m}$ higher than during the Alleröd). This is probably due to less vegetation and longer season of frozen soils, causing reduced percolation of water to groundwater and increased direct runoff into the lake. The palaeoecological record of Lake
Kremensko-5, Pirin Mountains covering YD show also increasing aridity and remarkable retreat of the Pinus, Picea and Betula curves related to colder climatic conditions (Atanassova \& Stefanova, 2003; Stefanova et al., 2006). Also, palaeoclimatic modelling based on simple glacier-flow model and statistical glacier-climate models of Egesen maximum advance (ca. 12,400-12,300 cal yr BP) suggest that after $12,700-12,600$ cal yr BP, summer temperature was ca. $3.5^{\circ} \mathrm{C}$ lower, with $20-30 \%$ less precipitation in the interior of the Alps. Winters were cold and dry, but summers were presumably only moderately drier or even wetter than today (Kerschner \& Ivy-Ochs, 2008).

Preboreal, 11,500-9300 cal yr BP $(105-0 \mathrm{~cm})$

Climatic warming at the Late-glacial-Holocene transition is inferred from a sharp increase of $\delta^{18} \mathrm{O}$ to ca. -8\%. Tree taxa including Betula, Fagus, Tilia, Quercus, Carpinus betulus, Carpinus orientalis/Ostrya, Alnus, Acer, Fraxinus excelsior type, Ulmus, Salix, Corylus and Abies started to increase, whereas Chenopodiaceae and Artemisia declined. The increase of profundal chironomids Micropsectra radialis and the decrease of littoral Cricotopus at the beginning of the zone may indicate an increase of water level. However, at 11,200 cal yr BP, Micropsectra radialis decreases sharply, and all the fauna typical for welloxygenated water disappears. Both species of Chironomus reach their maximum values. This is the typical situation in a mesotrophic/eutrophic lake that only support Chironomus, and other species adapted to survive under low oxygen concentrations (Hofmann, 1986; Walker, 2001). At ca. 10,400 cal yr BP, the conditions must have been favourable for cladocera, as it is the only interval when all the four taxa (Allona affinis, Acroperus harpae, Allonella nana and Chydorus spahericus) coexist. This assemblage is quite different from present-day cladoceran assemblages at Lake Bled, which are more planktonic (Daphnia hyalina, D. hyalina $\times$ galeata, Bosmina longispina, Diaphanosoma brachyurum and Scapholeberis kingi) (Brancelj, 1991), whereas benthic Cladocera are reduced due to the eutrophic condition of the lake. Allonella nana, which is present in the core, has not yet been found in the present-day fauna of Lake Bled (Brancelj, unpublished). The species is quite common in the littoral zone of oligotrophic-mesotrophic coldwater lakes. This conditions are no more existing in 
Lake Bled, which is mesotrophic-eutrophic warm water. Palaeoecological research at Lakes Gerzensee and Lautrey suggest a temperature rise of ca. $3^{\circ} \mathrm{C}$ at the Holocene transition in less than 50 years (Lotter et al., 2000; Lotter et al., in prep.; Schwander et al., 2000; von Grafenstein et al., 2000; Peyron et al., 2005).

In summary, at the beginning of Preboreal, the climate became warmer and wetter, with a mixed pine-broad-leaved forest around the lake. The water level increased, and the lake became deep again, holding favourable conditions for Cladocera and profundal chironomid assemblages.

\section{Conclusions}

Late-glacial terrestrial and aquatic ecosystems at Lake Bled were very dynamic, and several proxies responded to climatic change simultaneously, enabling more detailed reconstruction of environmental changes. Both ecosystems, i.e. terrestrial and aquatic, responded to changes of temperature, precipitation and hydrological conditions; therefore, our assumptions about past climate (e.g. temperature) are affected also by local (e.g. lake level) conditions.

Whereas in the Oldest Dryas the climate was cold and dry, later a trend towards wetter and warmer climate occurred, with the beginning of the precipitation of biogenic carbonates, suggested by the appearance of ostracods and an increase of aquatic plant macrofossils (e.g. Callitriche). By that time, Lake Bled water was well oxygenated and rich in vegetation (e.g. Callitriche, Scorpidium scorpidioides), and the lake was probably surrounded by predominantly herbaceous vegetation, with only very small populations of shrub and tree taxa. The climate became warmer, with an increase of tree cover (Betula, Larix) and warmer chironomid fauna, suggesting a well-oxygenated, more productive lake. Further climatic warming at $13,800 \mathrm{cal}$ yr BP led to increase of broad-leaved tree taxa (Quercus, Tilia, Ulmus) and Picea and lower lake levels, as indicated by Chironomid record.. Towards the end of this interstadial, the climate became colder and drier, as suggested by the $\delta^{18} \mathrm{O}$ record, increase of xerophytes and microcharcoal and lower lake levels (presence of littoral chironomids) after $12,800 \mathrm{cal} \mathrm{yr}$ BP. A warmer and wetter Preboreal climate after $11,500 \mathrm{cal}$ yr BP enabled the spread of broad-leaved tree taxa, whereas the lake became deeper (increase of profundal Chironomids) and mesotrophic/eutrophic, with lower oxygen content.

The local presence of a wide variety of tree taxa is not a surprise, given the proximity of Slovenia to fullglacial refugia (e.g. Willis \& van Andel, 2004; Cheddadi et al., 2006). Plant macrofossils suggest the local presence of Betula (probably from ca. 15,000 cal yr BP), Larix (probably ca. 14,500 cal yr BP), Picea (ca. 13,000 cal yr BP), Populus (ca. $12,000 \mathrm{cal} \mathrm{yr}$ BP) and Ephedra (probably ca. 14,700 cal yr BP), but surprisingly, no Pinus macrofossils were found. Although general vegetation development at Lake Bled is comparable to that of the neighbouring regions (e.g. northern Italy; Vescovi et al., 2007, Hungary; Willis et al., 1995, 2000), the stable-isotope record, in contrast to many lakes south of the Alps (Eicher, 1987), shows a distinct negative Younger Dryas $\delta^{18} \mathrm{O}$ signal (colder climate). A similar stable-isotope record is characteristic only for Lago Piccolo di Avigliana (Finsinger et al., 2008).

Future research should focus also on multi-proxy studies of Late-glacial and Holocene environmental change and human versus climatic impact on the environment at Lake Bled and other study sites in the region to better understand the present and future environmental changes.

Acknowledgments This research was partly funded by the Slovenian Research Agency (project Z6-4074-0618-03). We would like to thank Timotej Knific for his support, Willy Tanner and Mike Tanner for coring Lake Bled, and Mateja Belak for preparing figures. We thank Steve Brooks from the Natural History Museum of London for lab facilities during Julieta Massaferro postdoc and for his help with the chironomid identifications. We are very grateful to Herb Wright for critical comment on the manuscript and checking the English language. Comments from two anonymous referees are gratefully acknowledged.

\section{References}

Atanassova, J. \& I. Stefanova, 2003. Late-glacial vegetational history of Lake Kremensko-5 in the northern Pirin Mountains, southwestern Bulgaria. Vegetation History and Archaeobotany 12: 1-6.

Beijerinck, W., 1947. Zadenatlas der nederlandsche Flora. H. Veeman \& Zonnen, Wageningen.

Bengtsson, L. \& M. Ennell, 1986. Chemical analysis. In Berglund, B. E. (ed.), Handbook of Holocene Palaeoecology and Palaeohydrology. Wiley, New York: 423-451. 
Bennett, K. D., 1996. Determination of the number of zones in a biostratigraphical sequence. New Phytologist 132: 155-170.

Bennett, K. D., 1998. Documentation for PSIMPOLL 3.00 and PSCOMB 1.03: C programs for plotting pollen diagrams and analysing pollen data. http://chrono.qub.ac.uk/ psimpoll/psimpoll.html.

Bennett, K. D. \& K. J. Willis, 2002. Pollen. In Smol, J. P., H. J. Birks \& W. M. Last (eds), Tracking Environmental Changes Using Lake Sediments. Volume 3. Terrestrial, Algal and Siliceous Indicators. Kluwer Academic Publishers, Dordrecht: 5-32.

Birks, H., 2002. Plant macrofossils. In Smol, J. P., H. J. Birks \& W. M. Last (eds), Tracking Environmental Changes Using Lake Sediments. Volume 3. Terrestrial, Algal and Siliceous Indicators. Kluwer Academic Publishers, Dordrecht: 49-74.

Birks, H., 2003. The importance of plant macrofossils in the reconstruction of Late-glacial vegetation and climate: examples from Scotland, western Norway, and Minnesota, USA. Quaternary Science Reviews 22: 453-473.

Birks, H. J. B. \& A. D. Gordon, 1985. Numerical Methods in Quaternary Pollen Analysis. Academic Press, London.

Björck, S., M. J. C. Walker, L. C. Cwynar, S. Johnsen, K. L. Knudsen, J. J. Lowe, B. Wolfarth \& INTIMATE members, 1998. An event stratigraphy for the Last Termination in the North Atlantic region based on Greenland ice-core record: a proposal by the INTIMATE group. Journal of Quaternary Science 13: 283-292.

Bozilova, E., M. Filipova, L. Filipovich \& S. Tonkov, 1996. Bulgaria. In Berglund, B. E., H. J. B. Birks, M. RalskaJasiewiczowa \& H. E. Wright (eds), Palaeoecological Events During the Last 15,000 Years: Regional Syntheses of Palaeoecological Studies of Lakes and Mires in Europe. Wiley, Chichester: 701-728.

Brancelj, A., 1991. A model of the zooplankton production assessed in Daphnia hyalina (Crustacea: Cladocera) in the lake Blejsko jezero. Ph.D. Dissertation. University of Ljubljana, Department of Biology: 144 pp (in Slovene).

Brancelj, A., M. Śiško, G. Muri, P. Appleby, A. Lami, E. Shilland, N. L. Rose, C. Kamenik, S. J. Brooks \& J. A. Dearing, 2002. Lake Jezero v Ledvici (NW Slovenia)changes in sediment records over the last two centuries. Journal of Paleolimnology 28: 47-58.

CALIB 5.0 Website, 2006. http://calib.qub.ac.uk/.

Cheddadi, R., G. G. Vendarmin, T. Litt, L. François, M. Kageyama, S. Lorentz, J.-M. Laurent, J.-L. de Beaulieu, L. Sadori, A. Jost \& D. Lunt, 2006. Imprints of glacial refugia in the modern genetic diversity of Pinus sylvestris. Global Ecology and Biogeography 15: 271-282.

Clark, R. L., 1982. Point count estimation of charcoal in pollen preparations and thin sections of sediments. Pollen et Spores 24: 523-532.

Cranston, P. S., 1997. Identification Guide to the Chironomidae of New South Wales. Australian Water Technologies Pty Ltd., West Ryde.

Culiberg, M., 1991. Late Glacial Vegetation in Slovenia [Kasnoglacialna vegetacija v Sloveniji]. Dela SAZU IV/ 29, SAZU, Ljubljana.

Čarni, A., A. Marinček, A. Seliškar \& M. Zupančič, 2003. Vegetation map of Slovenian forest plant associations,
Institute of Biology, Scientific Research Centre of the Slovenian Academy of Sciences and Arts. http://bijh.zrcsazu.si/bio/si/zbirke/400/400.asp.

Davis, M. B., 1976. Erosion rates and land-use history in Southern Michigan. Environmental Conservation 3: 139-148.

Dearing, A. J. \& I. D. L. Foster, 1986. Lake sediments and palaeohydrological studies. In Berglund, B. E. (ed.), Handbook of Holocene Palaeoecology and Palaeohydrology. Wiley, New York: 67-90.

Digerfeldt, G., 1986. Studies on past lake-level fluctuations. In Berglund, B. E. (ed.), Handbook of Holocene Palaeoecology and Palaeohydrology. Wiley, New York: 127-143.

Dolenec, T., J. Pezdič, B. Ogorelec \& M. Mišič, 1984. Izotopska sestava kisika in ogljika $\mathrm{v}$ recentnem sedimentu iz Blejskega jezera in v pleistocenski jezerski kredi Julijskih Alp [The isotopic composition of oxygen and carbon of the recent sediment from the Bled Lake and of the Pleistocene lacustrine chalk from the Julian Alps]. Geologija 27: 161-170.

Eicher, U., 1987. Die spätglazialen sowie die frühpostglazialen Klimaverhältnisse im Bereiche der Alpen: Sauerstoffisotopenkurven kalkhaltiger Sedimente. Geographica Helvetica 42: 99-104.

Feurdean, A., B. Wohlfarth, L. Björkman, I. Tantau, O. Bennike, K. J. Willis, S. Farcas \& A. M. Robertsson, 2007. The influence of refugial population on Lateglacial and early Holocene vegetational changes in Romania. Review of Palaeobotany and Palynology 145: 305-320.

Feurdean, A., S. Klotz, S. Brewer, V. Mosbrugger, T. Tămas \& B. Wohlfarth, 2008. Lateglacial climate development in NW Romania-Comparative results from three quantitative pollen-based methods. Palaeogeography, Palaeoclimatology, Palaeoecology 265: 121-133.

Finsinger, W., C. Bellis, S. E. P. Blockley, U. Eicher, M. Leuenberger, A. F. Lotter \& B. Ammann, 2008. Temporal patterns in lacustrine stable isotopes as evidence for climate change during the late glacial in the Southern European Alps. Journal of Palaeolimnology, Open Access. doi 10.1007/s10933-008-9205-7.

Geological Map of Slovenia, 1993. 1: 500 000, Ljubljana, Geodetski zavod Slovenije.

Grimm, E., 1991 of Tilia and Tilia Graph. Illinois State Museum.

Grimšičar, A., 1955. Zapiski o geologiji Bleda. Notes about the geology of Bled area. Geologija 3: 220-225.

Heiri, O. \& L. Millet, 2005. Reconstruction of Late Glacial summer temperatures from chironomid assemblages in Lac Lautrey (Jura, France). Journal of Quaternary Science 20: $33-44$.

Hofmann, W., 1986. Chironomid analysis. In Berglund, B. E. (ed.), Handbook of Holocene Palaeoecology and Palaeohydrology. Wiley, New York: 715-723.

Ivy-Ochs, S., H. Kerschner, P. W. Kubik \& C. Schlüchter, 2006a. Glacier response in the European Alps to Heinrich Event 1 cooling: the Gschnitz stadial. Journal of Quaternary Science 21: 115-130.

Ivy-Ochs, S., H. Kerschner, A. Reuther, M. Maisch, R. Sailer, J. Schaefer, P. W. Kubik, H.-A. Synal \& C. Schlüchter, 2006b. The timing of glacier advances in the northern European Alps based on surface exposure dating with 
cosmogenic ${ }^{10} \mathrm{Be},{ }^{26} \mathrm{Al},{ }^{36} \mathrm{Cl}$, and ${ }^{21} \mathrm{Ne}$. Geological Society of America Special Paper 415: 43-60.

Jackson, S. T. \& R. K. Booth, 2007. Using plant macrofossils to refine and validate pollen studies. In Elias, S. A. (ed.), Encyclopedia of Quaternary Sciences. Elsevier, New York: 2413-2442.

Kaltenrieder, P., C. A. Belis, S. Hofstetter, B. Ammann, C. Ravazzi \& W. Tinner, in press a. Environmental and climatic conditions at a potential Glacial refugial site of tree species near the southern Alpine glaciers. New insights from multiproxy sedimentary studies at Lago della Costa (Eugaean Hills, northeastern Italy), Quaternary Science Reviews.

Kaltenrieder, P., G. Procacci, B. Vanniere \& W. Tinner, in press $b$. Postglacial vegetation and fire history of the Euganean Hills (Colli Euganei) as recorded by sedimentary pollen and charcoal series from Lago della Costa (northeastern Italy). The Holocene.

Katz, N., S. Katz \& M. Kipiani, 1977. Atlas and keys of fruits and seeds occurring in the quaternary deposits of the USSR, Moscow (in Russian).

Kerschner, H. \& S. Ivy-Ochs, 2008. Palaeoclimate from glacier: examples from the Eastern Alps during the Alpine Lateglacial and early Holocene. Global and Planetary Change 60: 58-71.

Korhola, A. \& M. Rautio, 2001. Cladocera and other branchiopod crustaceans. In Smol, J. P., H. J. B. Birks \& W. M. Last (eds), Tracking Environmental Change Using Lake Sediments. Volume 4: Zoological indicators. Kluwer Academic Publishers, Dordrecht, The Netherlands: 5-41.

Latałowa, M. \& W. O. van der Knaap, 2006. Late Quaternary expansion of Norway spruce Picea abies (L.) Karst. in Europe according to pollen data. Quaternary Science Reviews 25: 2780-2805.

Light, J. J. \& R. I. Lewis Smith, 1976. Deep-water bryophytes from the highest Scottish lochs. Journal of Bryology 9: 55-62.

Lister, G. S., 1988. A 15 000-year isotopic record from Lake Zürich of deglaciation and climatic change in Switzerland. Quaternary Research 29(2): 129-141.

Löffler, H., 1984. The palaeolimnology of Lake Bled (Blejsko jezero). Verhandlungen der Internationalen Vereingung für theoretische und angewandte Limnologie 22: 1409-1413.

Lojen, S., N. Ogrinc \& T. Dolenec, 1997. Carbon and nitrogen stable isotope fractionation in the sediment of Lake Bled (Slovenia). Water, Air and Soil Pollution 99: 315-323.

Lojen, S., N. Ogrinc \& T. Dolenec, 1999. Decomposition of sedimentary organic matter and methane formation in the recent sediment of Lake Bled (Slovenia). Chemical Geology 159: 223-240.

Lotter, A. F., H. J. B. Birks, U. Eicher, W. Hoffmann, J. Schwander \& L. Wick, 2000. Younger Dryas and Allerød summer temperatures at Gerzensee (Switzerland) inferred from fossil pollen and cladoceran assemblages. Palaeogeography, Palaeoclimatology, Palaeoecology 159(3-4), Special Issue: Ammann, B. (ed.), Biotic Responses to Rapid Climatic Changes Around the Younger Dryas: 349-361.

Lotter, A. F., O. Heiri, J. N. F. van Leeuwen, U. Eicher, J. Schwander \& B. Ammann, in prep. Rapid summer temperature changes during Termination 1: multi-proxy reconstructions from Gerzensee (Switzerland), Poster at the EGU 2008.

Lowe, J. J., W. Z. Hoek \& INTIMATE Group, 2001. Interregional correlation of palaeoclimatic records for the Last Glacial-Interglacial Transition: a protocol for improved precision recommended by the INTIMATE project group. Quaternary Science Reviews 20: 1175-1187.

Lowe, J. J., S. O. Rasmussen, S. Björck, W. Z. Hoek, J. P. Steffenson, M. J. C. Walker, Z. C. Yu \& INTIMATE group, 2008. Synchronisation of palaeoenvironmental events in the North Atlantic region during the Last Termination: a revised protocol recommended by the INTIMATE group. Quaternary Science Reviews 27: 6-17.

Magny, M., J.-L. De Beaulieu, R. Drescher-Schneider, B. Vannière, A.-V. Walter-Simonnet, L. Millet, G. Bousset \& O. Peyron, 2006. Climatic oscillations in central Italy during the Last Glacial-Holocene transition: the record from Lake Accesa. Journal of Quaternary Science 21: 311-320.

Magri, D., G. G. Vendramin, B. Comps, I. Dupanloup, T. Geburek, D. Gömöry, M. Latałowa, T. Litt, L. Paule, J. M. Roure, I. Tantau, W. O. van der Knaap, R. J. Petit \& J.-L. de Beaulieu, 2006. A new scenario for the Quaternary history of European beech populations: palaeobotanical evidence and genetic consequences. New Phytologist 171: 199-221.

Magyari, E., J. Chapman, B. Gaydarska, E. Marinova, T. Deli, J. Huntley, J. Allen \& B. Huntley, 2008. The 'oriental' component of the Balkan flora: evidence of presence on the Thracian Plain during the Weichselian late glacial. Journal of Biogeography 35: 865-883.

Martinčič, A., 1996. Barja. wetlands. In Gregori, J., A. Martinčič, K. Tarman, O. Urbanc-Brečič, D. Tome \& M. Zupančič (eds), Narava Slovenije, stanje in perspektive [Nature of Slovenia, Current State and Prospects for the Future]. Društvo ekologov Slovenije [Ecological Society of Slovenia] Ljubljana: 122-132.

Merkt, J. \& H. Streif, 1970. Stechrohr-Bohrgeräte für limnische und marine Lockersedimente. Geologische Jahrbuch 88: 137-148.

Molnar, F. M., P. Rothe, U. Förstner, J. Štern, B. Ogorelec, A. Šercelj \& M. Culiberg, 1978. Lakes Bled and Bohinj. Origin, composition, and pollution of recent sediments. Geologija 21: 93-164.

Moore, P. D., J. A. Webb \& M. E. Collinson, 1991. Pollen Analysis, 2nd ed. Blackwell Science, Oxford.

Nyholm, E., 1954-1969. Illustrated moss flora of Fennoscandia II. Musci (fasc. 1-6). Botanical Society of Lund, Stockholm: $799 \mathrm{pp}$.

Ogrin, D., 1996. Podnebni tipi v Sloveniji [The climate types in Slovenia]. Geografski vestnik 68: 39-56.

Ogrinc, N., S. Lojen \& J. Faganeli, 1997. The sources of dissolved inorganic carbon in pore waters of lacustrine sediment. Water, Air and Soil Pollution 99: 333-341.

Ogrinc, N., S. Lojen, J. Faganeli, B. Čermelj, T. Dolenec \& J. Pezdič, 1998. Carbon cycling in a lacustrine environment (Lake Bled). RMZ-Materials and Geoenvironment 45: 136-140.

Ogrinc, N., S. Lojen \& J. Faganeli, 2002. A mass balance of carbon stable isotopes in an organic-rich methane- 
producing lacustrine sediment (Lake Bled, Slovenia). Global and Planetary Change 33: 57-72.

Pak, M., 2001. Savska raven. In Perko, D. \& O. M. Adamič (eds), Slovenija. Pokrajine in ljudje. Založba Mladinska knjiga, Ljubljana: 84-95.

Petit, R., I. Aguinagalde, J.-L. de Beaulieu, C. Bittkau, S. Brewer, R. Cheddadi, R. Ennos, S. Fineschi, D. Grivet, M. Lascoux, A. Mohanty, G. Müller-Starck, B. DemesureMusch, A. Palmé, J. P. Martin, S. Rendell \& G. G. Vendramin, 2003. Glacial refugia: hotspots but not melting pots of genetic diversity. Science 300: 1563-1565.

Peyron, O., C. Bégeot, S. Brewer, O. Heiri, M. Magny, L. Millet, P. Ruffaldi, E. Van Campo \& G. Yu, 2005. LateGlacial climatic changes in Eastern France (Lake Lautrey) from pollen, lake-levels, and chironomids. Quaternary Research 64: 197-211.

Radinja, D., S. Buser \& D. Vrhovšek, 1987. Blejsko jezero. Lake Bled. In Adamič, F., V. Bračič, M. Čepič, R. Godec, B. Grafenauer, M. Kališnik, J. Kastelic, A. Kornhauser, G. Počkar, M. Rožman, F. Šali \& I. Tavčar (eds), Enciklopedija Slovenije 1 [Encyclopedia of Slovenia 1]. Mladinska knjiga, Ljubljana: 289-291.

Ravazzi, C., M. Donegana, E. Vescovi, E. Arpenti, M. Caccianiga, P. Kaltenrieder, L. Londeix, S. Marabini, S. Mariani, R. Pini, G. Battista Vai \& L. Wick, 2006. A new Late-glacial site with Picea abies in the northern Apennine foothills: an exception to the model of glacial refugia of trees. Vegetation History and Archaeobotany 15: 357-371.

Reille, M., 1992. Pollen et Spores d'Europe et d'Afrique Du Nord. Laboratoire de Botanique Historique et Palynologie, URA, CNRS, Marseille.

Reille, M., 1995. Pollen et Spores d'Europe et d'Afrique Du Nord (Supplement). Laboratoire de Botanique Historique et Palynologie, URA, CNRS, Marseille.

Reimer, P. J., M. G. L. Baillie, et al., 2004. INTCAL04 terrestrial radiocarbon age calibration, 0-26 cal kyr BP. Radiocarbon 46: 1029-1058.

Scholz, C. A., 2001. Applications of seismic sequence stratigraphy in lacustrine basins. In Last, W. M. \& J. P. Smol (eds), Tracking environmental change using lake sediments. Volume 1: Basin analysis, coring and chronological techniques. Kluwer Academic Publishers, Dordrecht: 7-22.

Schultze, E., 1984. Beiträge zur Paläolimnologie des Bled-Sees in Slowenien (Jugoslawien) und zur Vegetations- und Klimaentwicklung der Umgebung. Geologija 27: 97-106.

Schultze, E., 1988. Fallstudien zur Paläolimnologie [Case studies on paleolimnology]. Geologija 31(32): 437-516.

Schwander, J., U. Eicher \& B. Ammann, 2000. Oxygen isotopes of lake marl at Gerzensee and Leysin (Switzerland), covering the Younger Dryas and two minor oscillations, and their correlation to the GRIP ice core. Palaeogeography, Palaeoclimatology. Palaeoecology 159: 203-214.

Seppä, H. \& S. Hicks, 2006. Integration of modern and past pollen accumulation rate (PAR) records across the arctic tree-line: a method for more precise vegetation reconstructions. Quaternary Science Reviews 25: 1501-1516.

Siegenthaler, U. \& U. Eicher, 1986. Stable oxygen and carbon isotope analyses. In Berglund, B. E. (ed.), Handbook of Holocene Palaeoecology and Palaeohydrology. Wiley, Chichester: 407-422.
Smith, A. J. E., 2004. The Moss Flora of Britain and Ireland, 2nd ed. Cambridge University Press, Cambridge: 1012 pp.

Stefanova, I. \& B. Ammann, 2003. Lateglacial and Holocene vegetation belts in the Pirin Mountains (southwestern Bulgaria). The Holocene 13: 97-107.

Stefanova, I., J. Atanassova, M. Delcheva \& H. E. Wright, 2006. Chronological framework for the Lateglacial pollen and macrofossil sequence in the Pirin Mountains, Bulgaria: Lake Besbog and Lake Kremensko-5. The Holocene 16: 877-892.

Stockmarr, J., 1971. Tablets with spores used in absolute pollen analysis. Pollen et Spores 13: 615-621.

Stuiver, M. \& P. Reimer, 1993. Extended 14C database and revised CALIB radiocarbon calibration program. Radiocarbon 35: 215-230.

Telford, R. J., E. Heegaard \& H. J. B. Birks, 2004. The intercept is a poor estimate of a calibrated radiocarbon age. The Holocene 14(2): 296-298.

Tobolski, K., 2000. A Guide to Peat and Lake Deposits. Vademecum Geobotanicum. Naukowe PWN, Warszawa: 508 pp (in Polish with English summary).

Van der Knaap, W. O., J. F. N. van Leeuwen \& B. Ammann, 2001. Seven years of annual pollen influx at the forest limit in the Swiss Alps studied by pollen traps: relations to vegetation and climate. Review of Palaeobotany and Palynology 117: 31-52.

Van der Knaap, W. O., J. F. N. van Leeuwen, W. Finsinger, E. Gobet, R. Pini, A. Schweizer, V. Valsecchi \& B. Ammann, 2005. Migration and population expansion of Abies, Fagus, Picea and Quercus since 15000 years in and across the Alps, based on pollen-percentage threshold values. Quaternary Science Reviews 24: 645-680.

Vannière, B., G. Bossuet, A.-V. Walter-Simonnet, P. Ruffaldi, T. Adatte, M. Rossy \& M. Magny, 2004. High-resolution record of environmental changes and tephrachronological markers of the Last Glacial-Holocene transition at Lake Lautrey (Jura, France). Journal of Quaternary Science 19: 797-808.

Vescovi, E., C. Ravazzi, E. Arpenti, W. Finsinger, R. Pini, V. Valsecchi, L. Wick, B. Ammann \& W. Tinner, 2007. Interactions between climate and vegetation during the Late glacial period as recorded by lake and mire sediment archives in Northern Italy and Southern Switzerland. Quaternary Science Reviews 26: 1650-1669.

Von Grafenstein, U., U. Eicher, H. Erlenkeuser, P. Ruch, J. Schwander \& B. Ammann, 2000. Isotope signature of the Younger Dryas and two minor oscillations at Gerzensee (Switzerland): palaeoclimatic and palaeolimnologic interpretation based on bulk and biogenic carbonates, Palaeogeography, Palaeoclimatology, Palaeoecology 159(3-4), Special Issue: Ammann, B. (ed.), Biotic Responses to Rapid Climatic Changes Around the Younger Dryas: 215-229.

Vrhovšek, D., G. Kosi \& M. Zupan, 1982. The effect on water chemistry and phytoplankton of artificial inflow of the River Radovna into Lake Bled (Yugoslavia). Hydrobiologia 96: 225-242.

Vrhovšek, D., G. Kosi, M. Kralj \& M. Bricelj, 1984. The effect of three consequent sanation measures in Lake Bled on physico-chemical and biological variables. Ekologija 19: 31-52. 
Vrhovšek, D., G. Kosi, M. Kralj, M. Bricelj \& M. Zupan, 1985. The effect of lake restoration measures on the physical, chemical and phytoplankton variables of Lake Bled. Hydrobiologia 127: 219-228.

Walker, I. R., 2001. Midges: chironomidae and related Diptera. In Smol, J. P., H. J. B. Birks \& W. M. Last (eds), Tracking Environmental Change Using Lake Sediments, Vol. 4. Zoological Indicators. Kluwer Academic Publishers, Dordrecht: 43-66.

Wiederholm, T., 1983. Chironomidae of the Holarctic region. Keys and diagnoses. Part 1. Larvae. Entomologica Scandinavica Supplement 19: 1-457.
Willis, K. J. \& T. H. van Andel, 2004. Trees or no trees? The environments of central and eastern Europe during the Last Glaciation. Quaternary Science Reviews 23: 23692387.

Willis, K. J., P. Sümegi, M. Braun \& A. Tóth, 1995. The late Quaternary environmental history of Bátorliget, N. E. Hungary. Palaeogeography, Palaeoclimatology, Palaeoecology 118: 25-47.

Willis, K. J., E. Rudner \& P. Sümegi, 2000. The Full-Glacial forests of central and southeastern Europe. Quaternary Research 53: 203-213. 